The basis problems resulting from the death of a reversioner-settlor of an inter vivos trust highlight the present uneasy state of applicable law. Two principles, however, are clear: All taxpayers acquiring property from a decedent should receive equal basis treatment; and basis should be allowed only if, and to the extent that it has been "paid for" within the framework of the Code.

While the recommendations of this comment reflect the inherent complexity of the problem, they amount essentially to this: In determining proper basis, and hence tax liability, the various outstanding property interests created by use of the trust form should receive the benefit of any taxable events which initially affect any one of these related interests. Treating these interests separately, as would apparently be done upon mechanical application of present statutory provisions, is unnecessary as well as inequitable.

\title{
PROXY CONTESTS: CORPORATE REIMBURSEMENT OF INSURGENTS' EXPENSES
}

Until recently, no court had considered the questions of whether and to what extent corporate funds properly may be employed to defray the expenses of proxy solicitations incurred either by successful or unsuccessful insurgent shareholders in contests for control of the board of directors. ${ }^{1}$ No reported decision yet appears concerning unsuccessful insurgents, and only two have dealt at any length with successful insurgents. ${ }^{2}$ These indicate that where insurgent share-

1 Other discussions of insurgents' proxy expenses are found in Emerson and Latcham, Shareholder Democracy, c. 6 (1954), and a series of articles by these authors: Proxy Contests: Competition for Management Through Proxy Solicitation, 8 So. West. L.J. 403 (1954); Proxy Contest Expenses and Shareholder Democracy, 4 West. Res. L. Rev. 5 (1952); Proxy Contests: A Study in Shareholder Sovereignty, 41 Calif. L. Rev. 393 (1953). Consult also Friedman, Expenses of Corporate Proxy Contests, 51 Col. L. Rev. 951 (1951); Financing Proxy Contests With Corporate Funds, 44 Geo. L.J. 303 (1956); Expenses of a Proxy FightThe Problem of Reimbursement by the Corporation, 10 So. West. I.J. 44 (1956); Corporations: Reimbursement for Corporate Campaign Expenses Incurred in Proxy Fights, 43 Calif. L. Rev. 893 (1955); 7 West. Res. L. Rev. 198 (1956), noting Rosenfeld v. Fairchild Engine \& Airplane Corp., 309 N.Y. 168, 128 N.E. 2d 291 (1955); and 61 Yale L.J. 229 (1952), 36 Cornell L.Q. 558 (1951), noting Steinberg v. Adams, 90 F. Supp. 604 (S.D. N.Y., 1950).

For a discussion of various other issues which evoke solicitations by opposition groups consult the following articles by Emerson and Latcham: Proxy Contests: Competition for Management Through Proxy Solicitation, 8 So. West. L.J. 403 (1954); 41 Calif. L. Rev. 393 (1953); The SEC Proxy Proposal Rule: The Corporate Gadfly, 19 U. of Chi. L. Rev. 807 (1952).

2 Only three reported cases have dealt with the problem. Rosenfeld v. Fairchild Engine \& Airplane Corp., 309 N.Y. 168, 128 N.E. 2d 291 (1955); Cullom v. Simmonds, 285 App. Div. 1051, 139 N.Y.S. 2d 401 (2d Dep't, 1955); Steinberg v. Adams, 90 F. Supp. 604 (S.D. N.Y., 1950) (applying Delaware law).

Some reasons may be advanced for the lack of cases: (1) the infrequency of successful insurgencies; (2) the seeming finality of shareholder ratification; (3) the apathy of most shareholders; and (4) the risk of paying the entire cost of litigation if unsuccessful in "making law" on this subject. Traditionally the "outs" have borne the cost of their failure, and it has apparently not occurred to them that there may be a basis for claiming reimbursement. 
holders successfully gain control in a contest over "policy" as distinct from "a purely personal power contest," a majority of the shareholders may reimburse them for "reasonable and bona fide expenses."

The purpose of this comment is to examine the propriety of corporate reimbursement of insurgents-whether successful or otherwise-as well as the permissible nature and extent of the expenditures for which they may be reimbursed.

\section{I}

Steinberg v. Adams, ${ }^{4}$ decided in 1950, is the earliest reported case involving the insurgent problem. The insurgents had won control of the board of directors in a proxy battle. By a resolution, later approved by a majority of the shareholders, the insurgents caused the company to reimburse both the former directors and themselves for solicitation expenses incurred by each group. In a derivative action by a minority shareholder against the insurgent directors to recover these funds, motions on each side for summary judgment were denied because the pleadings contained a material issue of fact as to whether the proxy contest had concerned matters of policy as distinct from a contest for personal control..$^{5}$ In the course of the opinion, the court said that successful insurgents, having rid the corporation of the policies "frowned upon by the majority," should be entitled to reimbursement upon majority shareholder approval. This was considered "permissible" in view of the practice of allowing incumbents access to corporate funds win or lose. The court also analogized the insurgents' situation to that of a shareholder who "is reimbursed regardless of the views of the stockholders" for his litigation expenses if he successfully litigates a derivative suit for the benefit of the corporation.

The second decision is that of the New York Court of Appeals in Rosenfeld v. Fairchild Engine \& Airplane Corp. ${ }^{6}$ a three-one-three decision upholding the reimbursement of successful insurgents. This was a derivative suit by a minority shareholder against the leader of the successful insurgents and others for the

${ }^{3}$ Rosenfeld v. Fairchild Engine \& Airplane Corp., 309 N.Y. 168, 173, 128 N.E. 2d 291, 293 (1955).

490 F. Supp. 604 (S.D. N.Y., 1950).

"Judge Rifkind pointed out the tremendous difficulty of separating these issues in practice. Ibid., at 608 . The dubious value of the distinction has been recognized by other courts and writers with respect to both insurgents and incumbent management. See especially, Rosenfeld v. Fairchild Engine \& Airplane Corp., 309 N.Y. 168, 183, 128 N.E. 2d 291, 299 (1955); Hall v. Trans-Lux Daylight Picture Screen Corp., 20 Del. Ch. 78, 171 Atl. 226 (1934). Consult Corporations-Corporate Policy, The "Cure-All" For Proxy Solicitation Ailments, 49 Mich. L. Rev. 605 (1951). But cf. Lawyers' Advertising Co. v. Consolidated Ry. Lighting \& Refrigerating Co., 187 N.Y. 395, 80 N.E. 199 (1907), a much discussed decision disallowing certain of the incumbent's advertising expenditures partially on the ground that they were used to further a dispute for control between factions. This case illustrates that, although difficult of application, the "policy" requirement is not to be disregarded.

6 309 N.Y. 168, 128 N.E. 2 d 291 (1955). 
return of corporate funds used to defray the proxy solicitation expenses of both the successful insurgents and the defeated directors. As in the Steinberg case, reimbursement of the insurgents had been approved by a majority of the shareholders. ${ }^{7}$

In framing the issue, Judge Froessel, writing for three members of the court, said that the plaintiff's counsel conceded that " 'the charges were fair and reasonable,' but denied 'they were legal charges which may be reimbursed for.' "' Thus this was not a case in which "a stockholder challenges specific items, which, on examination, the trial court may find unwarranted, excessive or otherwise improper." These judges held that the shareholders as owners of a corporation had the right to reimburse successful insurgents for reasonable and bona fide expenses of the proxy contest. This was true even though the insurgents-who, unlike incumbent directors, were under no duty to inform the shareholders of the corporate circumstances - may have been unable to insist upon reimbursement.

Judge Desmond, specially concurring, rested his decision entirely on the lack of sufficient evidence in the record to make out a prima facie case that any of the specific expenditures were unlawful or their amount unreasonable. Since the record clearly indicated the total expenditures for which the insurgents were reimbursed, it may be inferred that in his view at least some reimbursement of successful insurgents was not "intrinsically unlawful" and could therefore have been ratified by less than a unanimous vote. Though admittedly dicta, Judge Desmond's further comments indicate that the extent to which corporate funds may be used for proxy solicitation in addition to "giving notice of the meeting, and of the questions to be voted on" is rather limited.10

To the three dissenting judges, any reimbursement of successful insurgents by the corporation would serve no legitimate "corporate purpose" and hence could not be ratified over the objection of even a single dissenting shareholder. Several arguments were advanced. First, insurgents, unlike incumbents, are

7 The new board had reimbursed itself and also paid out some funds to cover the unpaid portion of the expenses incurred by the old board. It is not clear that the shareholder ratification was meant to cover the latter. Ibid., at pp. 179,296. The total cost to the corporation was about $\$ 261,000$ of which $\$ 127,000$ was paid to the insurgents. The expenses of both sides included printing, stationery, postage, public relations counsel, proxy solicitors, and entertaining stockholders. Ibid., at 180, 297, and Rosenfeld v. Fairchild Engine \& Airplane Corp., 116 N.Y.S. 2d 843, 845 (S. Ct., 1952).

For a detailed picture of proxy campaign practices consult Emerson and Latcham, Further Insight into More Effective Stockholder Participation: The Sparks-Withington Proxy Contest, 60 Yale L.J. 429 (1951).

8 Rosenfeld v. Fairchild Engine \& Airplane Corp., 309 N.Y. 168, 172, 128 N.E. 2d 291, 292 (1955).

${ }^{9}$ Ibid.

${ }^{10}$ Ibid., at 175-76, 294-95. In this discussion, he does not distinguish between the activities of incumbents and successful insurgents, nor does he make it clear whether such reimbursement as would be permissible must be ratified to be effective. Consult discussion at p. 688 infra. 
"mere groups of shareholders" and hence under no duty to inform and advise other shareholders of corporate affairs. Second, a change of management is in no sense analogous to an adjudication by a court that the former management had been guilty of misconduct or mismanagement-thus, in their opinion, destroying the analogy suggested by Judge Rifkind in the Steinberg case to the reimbursement of a shareholder who successfully litigates a derivative suit against the management. ${ }^{.1}$ It was further considered that resting the right to reimbursement on the ultimate success of the campaign would ignore the possible benefit which may accrue to the corporation from even an unsuccessful insurgency. ${ }^{12}$ Finally, the dissenters saw the prospect of reimbursement as offering a powerful incentive in addition to control which would tend to result in extensive and expensive campaigns by both the "ins" and the "outs."

In testing these decisions and other problems of law and policy which may be anticipated, it would be well to consider first the basis upon which the use of corporate funds for proxy solicitation by any group is justified. Since corporate welfare is traditionally considered to require that shareholders as owners of the corporation be sufficiently well informed to vote intelligently, corporate directors are under a duty to inform and advise the shareholders concerning the wisdom of the policies advocated by the management. Any "reasonable" expenditures incurred in fulfilling this obligation may be taken from the corporate treasury provided the contest involves a matter of "policy" as opposed to a contest for personal power. ${ }^{13}$

11 Consult discussion at p. 687 infra.

12 This argument may also be used with equal force to justify at least partial reimbursement of unsuccessful insurgents' expenditures. Consult discussion at p. 690 infra.

13 E.g., Hand v. Missouri-Kansas Pipe Line Co., 54 F. Supp. 649 (D. Del., 1944); Hall v. Trans-Lux Daylight Picture Screen Corp., 20 Del. Ch. 78, 171 Atl. 226 (1934); Peel v. London \& North Western Ry. Co. [1906], 1 Ch. Div. 5 (1907).

Our present legal concept of shareholder ownership and control has been questioned by some writers. The resulting suggestions would provide that in large corporations virtually complete control of corporate affairs be exercised by the management with varying degrees of supervision by government and a reorganized board of directors. Such changes are considered necessary chiefly because of: (1) the conflict of interest between management-favoring reinvestment of earnings and other growth practices to achieve personal power and prestigeand shareholders-favoring current distribution of earnings; (2) the need to protect the interest of employees, consumers, and the general public from excessive shareholder pressure for dividends; and (3) the apathy of shareholders in large widely held corporations and management control of the proxy system which combine to undermine the usefulness of shareholder "control." Drucker, The New Society 339-44 (1950) (advocating that stock ownership in large corporations be considered purely an investment and carry no ownership or "control" rights); Gordon, Business Leadership in the Large Corporation 347-50 (1945); 2 Berle and Means, The Modern Corporation and Private Property, c. 8 (1932).

Whether or not such changes are desirable, it seems unlikely that they will be made in the near future. More probably the problem of management-shareholder relations will concern the renewed use of proxy solicitation machinery. Compare, Berle, For Whom Corporate Managers Are Trustees, 45 Harv. L. Rev. 1365 (1932), with Dodd, For Whom Are Corporate Managers Trustees?, 45 Harv. L. Rev. 1145 (1932), and Dodd, Is Effective Enforcement of the Fiduciary Duties of Corporate Managers Practicable? 2 U. of Chi. L. Rev. 194 (1935), highlighting the need for caution. 
A similar concept of corporate "benefit"14 would seem to justify some use of corporate funds to defray the costs of wholesome activity by insurgents although the courts have not considered them to be under a similar duty to inform and advise the other shareholders..$^{15}$ In order to obtain full presentation of corporate problems, groups in opposition to the management should be encouraged to present interpretations of the facts which may not otherwise reach the shareholders. They should be encouraged to submit proposals and offer candidates to implement their proposals where that is the most practical means of achieving these goals. ${ }^{16}$

Although the ultimate effect of the new management on profits usually cannot be accurately measured even by hindsight, the insurgents' success indicates at least that a majority of those most concerned considered the change beneficial. ${ }^{17}$

Furthermore, incumbent management's access to corporate funds as the costs are incurred as well as the lack of judicially sanctioned reimbursement of insurgents' expenses has traditionally placed the "outs" at a disadvantage. ${ }^{18}$ This could be at least partially equalized, and the objective of increased shareholder participation in corporate affairs furthered by a consistent policy of reimbursement in proper cases.

It seems more desirable to decide the problem of insurgents' reimbursement independently within the rubric of corporate proxy solicitations than to rely

14 The meaning of corporate benefit as here used is extended beyond the usual tangible benefit which is capable of market valuation. Compare Kerbs v. California Eastern Airways, 33 Del. Ch. 69, 90 A. 2d 652 (1952), modified on other grounds, 33 Del. Ch. 395, 94 A. 2d 217 (1953) (involving an executive stock option plan).

${ }^{15}$ See Rosenfeld v. Fairchild Engine \& Airplane Corp., 309 N.Y. 168, 173, 128 N.E. 2d 291, 293 (1955). But compare the dissenting opinion at pp. 184, 300 and 36 Cornell L.Q. 558 (1951), noting Steinberg v. Adams, 90 F. Supp. 604 (S.D. N.Y., 1950), arguing that this lack of duty should be controlling.

${ }^{16}$ The Securities and Exchange Commission has given the need limited recognition by the adoption of Rule X-14A-8, 17 Code Fed. Reg. $\$ 240.14 a-8$ (Cum. Supp., 1956), which requires management to include in its proxy materials at least 100 words by a shareholder in favor of a "proper" shareholder proposal which the management plans to oppose. However, an opposition slate of candidates is specifically excluded.

It has been suggested that such nominations be included within the rule. Emerson and Latcham, Shareholder Democracy, supra note 1, at 79, 106; Caplin, Shareholder Nominations of Directors: A Program for Fair Corporate Suffrage, 39 Va. L. Rev. 141 (1953); Emerson and Latcham, The SEC Proxy Proposal Rule: The Corporate Gadfly, supra note 1; Caplin Proxies, Annual Meetings and Corporate Democracy: The Lawyer's Role, 37 Va. I. Rev. $653,682-85$ (1951).

${ }^{17}$ One writer, although recognizing the extreme difficulty of proving or disproving a substantial tangible benefit in such cases, recommends that majority shareholder approval be regarded as a "presumption" requiring an objecting shareholder to prove that no substantial benefit has in fact occurred upon which reimbursement may be based. Financing Proxy Contests with Corporate Funds, 44 Geo. I.J. 303, 310 (1956).

${ }^{18}$ E.g., see Berendt v. Bethlehem Steel Corp., 108 N.J. Eq. 148, 154 Atl. 321 (1931). Consult Berle and Means, The Modern Corporation and Private Property $80-90$ (1932); 5 Fletcher, Cyc. Corp. $\$ 2058.1$ (rev. ed., 1952); Ballantine, Corporations $\$ 180$ (rev. ed., 1946). 
upon analogies to less closely related areas of corporation law. An analogy has been drawn to the cases allowing a plaintiff shareholder to be reimbursed for litigation expenses, after successfully concluding a derivative action for the benefit of the corporation, regardless of the views of the other shareholders. ${ }^{19}$ Here the successful litigant has demonstrated to a court that there has been misconduct with respect to corporate affairs. Similarly, it is said, the successful insurgent has convinced a majority of the shareholders that the corporation has not been wisely managed. However, these cases require some tangible gain to the corporation-removal of a restriction or recovery of a claim-from which the court can award the reimbursement costs. ${ }^{20} \mathrm{It}$ is not easily argued that successful insurgents have produced such a tangible benefit. ${ }^{21}$ Usually, even hindsight will not reveal whether a successful insurgency has resulted in increased profits.

It may be inferred that a few writers ${ }^{22}$ would claim much stronger support from the cases in which some courts, regardless of any showing of tangible benefit, allow corporate reimbursement of litigation expenses to a director or officer who successfully defends against a mismanagement suit. ${ }^{23}$ The modern decisions rest partially on the rationale that this enables corporations to obtain talented men for responsible positions which would otherwise bear excessive

${ }^{19}$ See Steinberg v. Adams, 90 F. Supp. 604 (S.D. N.Y., 1950).

${ }^{20}$ E.g., Sprague v. Ticonic Nat'l Bank, 307 U.S. 161, 168 (1939) (establishing a lien on earmarked funds in an insolvent bank); New York Central R.R. Co. v. New York \& Harlem R.R. Co., 275 App. Div. 604, 90 N.Y.S. 2d 309 (1st Dep't, 1949), aff'd 301 N.Y. 567, 93 N.E. 2d 451 (1950) (removal of tax lien); Hornstein, The Counsel Fee in Stockholder's Derivative Suits, 39 Col. L. Rev. 784, 799 (1939).

${ }^{21}$ Consult 36 Cornell L.Q. 558 (1951), noting Steinberg v. Adams, 90 F. Supp. 604 (S.D. N.Y., 1950), concluding that successful insurgents should therefore not be reimbursed. Note that the policies of the successful insurgents may produce immediate financial savings. In the Rosenfeld case, for example, it was argued that settlement of an executive employment contract and other claims saved from $\$ 350,000$ to $\$ 825,000$, and management reorganization about $\$ 300,000$ per year. 309 N.Y. 168, 184, 128 N.E. 2 2d 291, 299 (1955). In such a case the analogy has much more force. However, it seems undesirable to rest the right to reimbursement upon the fortuitous circumstance that this kind of an issue will be involved in the insurgency. Furthermore, as discussed in part III infra, the reimbursement of insurgents is to be measured by the "reasonableness" of the expenditures made rather than primarily by the value of the benefit recovered as is true of litigation expense awards. For a discussion of the measure of litigation expenses to be awarded see Pergamet v. Kaiser-Frazer Corp., 224 F. 2d 80, 83 (C.A. 6th, 1955); and consult Hornstein, op. cit. supra note 20.

22 Consult, e.g., Emerson and Latcham, Shareholder Democracy 77 (1954); Friedman, Expenses of Corporate Proxy Contests, 51 Col. L. Rev. 951, 958-59 (1951). These writers have applied the analogy to justify the reimbursement of unsuccessful insurgents-an even more difficult case.

${ }^{23}$ E.g., In re Dissolution of E. C. Warner, 232 Minn. 207, 45 N.W. $2 \mathrm{~d} 388$ (1950); Solomine v. Hollander, 129 N.J. Eq. 264, 19 A. 2d 344 (1941). An older rule, stricter and less reasonable, required that successful defendants show a corporate benefit to justify expenditure. The danger of suits was regarded as a hazard of the office. E.g., New York Dock Co. v. McCollum, 173 N.Y. Misc. 106, 16 N.Y.S. 2d 844 (S. Ct., 1939). For a discussion of the statutory modifcations of this rule consult Ballantine, Corporations $\$ 157$ (rev. ed., 1946); Hornstein, Directors' Expenses in Stockholders' Suits, 43 Col. L. Rev. 301-16 (1943). 
risks. Just as corporate welfare requires talented personnel, it would seem to require active and intelligent shareholder participation. But even if this is true, ${ }^{24}$ there is still a significant difference. The director is compelled to incur expenses in order to demonstrate that he has not breached his trust. It seems unjust and unreasonable to thrust the full burden of unjust litigation upon him when he has satisfied the court of his innocence, at least where the defense was on the merits of the issue. The insurgent shareholder, however, voluntarily incurs solicitation expenses to bring about a change of management for reasons of business judgment which are vastly different from the more drastic events necessary to bring about court interference with the directors' operation of the business.

It can be concluded that reimbursement of successful insurgents does serve a "corporate purpose." This approach justifies the Steinberg-Rosenfeld theory that majority shareholder approval is sufficient to allow reimbursement despite minority objection. It is not clear, however, whether such approval is or should be a required prerequisite.

No case has yet been decided in which the successful insurgents had not obtained majority shareholder approval before reimbursing themselves, and the available dicta offer little assistance. The Steinberg court was equivocal. Although stating that there should be "no distinction" between the "ins" (whose reimbursement requires no prior shareholder approval) and the successful "outs," and analogizing the successful insurgent to the successful plaintiff in a shareholder's derivative suit to whom litigation expenses may be reimbursed "regardless of the views of the stockholders," the court concluded only that reimbursement is permissible "at least where there is approval by both the board of directors and a majority of the stockholders. ${ }^{25}$ Of the seven judges comprising the Rosenfeld court, three hinted that approval was necessary. Indicating that a majority of the owners of the corporation could allow reimbursement, they referred with approval to the opinion of the Appellate Division wherein it was asserted that, " $[t]$ he 'outs' in this case clearly were not entitled to reimbursement in the absence of stockholder approval. . ."26 The single concurring judge, however, discussed the problem in terms of "corporate expenditures" without distinguishing between insurgents' and incumbents' activities, thus allowing the inference that shareholder approval of insurgents' expenditures as with those of incumbents is unnecessary.

There does not appear to be a close legal analogy upon which the courts might allow reimbursement without prior majority shareholder approval. To say that the underlying principle of corporate welfare which justified incumbent management's access to corporate funds may also justify the basic right of in-

${ }^{24}$ Some writers argue that the presence of competent management removes the need for the traditional concepts of shareholder control. Consult discussion note 13 supra.

${ }^{25}$ Steinberg v. Adams, 90 F. Supp. 604 (S.D. N.Y., 1950).

${ }^{26}$ Rosenfeld v. Fairchild Engine \& Airplane Corp., 284 App. Div. 201, 209, 132 N.Y.S. 2d 273, 281 (3d Dep't, 1954). 
surgents to reimbursement does not answer the problem. The incumbents are under a duty to the corporation which carries the threat of liability for nonperformance. It seems "highly unreasonable" to require the directors personally to defray the expenses incurred in the proper satisfaction of this obligation. ${ }^{27}$ This reasoning cannot easily be applied to the voluntary exercise of a privilege by insurgents who, as pointed out by the dissenting judges in the Rosenfeld case, "may confidently be relied upon to reimburse themselves whatever may be the real merits of the controversy."28

While the existing decisions indicate that majority shareholder approval would probably be considered a necessary condition to obtaining reimbursement, it may be argued that such approval should not be required. Firstly, the extent to which such a requirement would serve any real purpose may be questioned. In the sweep of a contested election the shareholder approval is likely to become a mere formality easily obtained by the successful group now in control of the proxy machinery. Even where insurgents initially purport to abstain from any use of corporate funds, it would not seem difficult to convince the shareholders that the practices of the management "forced" expenditures beyond those estimated and hence justified reimbursement. ${ }^{29}$ Furthermore, if the wholesome activities of insurgents are to be encouraged, it seems sufficient to utilize shareholder approval as partial evidence of the propriety of reimbursement rather than as a necessary element. ${ }^{30} \mathrm{~A}$ court might rest a decision allowing reimburse-

${ }^{27}$ Cases cited in note 13 supra.

${ }^{28}$ Rosenfeld v. Fairchild Engine \& Airplane Corp., 309 N.Y. 168, 185, 128 N.E. 2d 291, 300 (1955). Consult Geo. L.J., op. cit. supra note 1.

${ }^{20}$ This was the strategy used by Mr. Young in obtaining shareholder approval of the insurgents' expenses after gaining control of the New York Central Railroad. See Amended and Supplemental Complaint, Greenberger v. New York Central R. Corp., No. 55 C 7844 (Circuit Ct. Cook County, Ill., 1955).

In the Rosenfeld case it was argued that the statements of insurgents that the solicitation was being made at their personal expense were merely to satisfy the requirement of the Securities and Exchange Commission that the proxy statement contain the "names of the persons by whom the cost of the solicitation has been or will be borne, directly or indirectly" (item 3[c] of Schedule 14A, 17 Code Fed. Regs. \& 240.14a-10 [Cum. Supp., 1955]). Answering Brief of Defendant-Respondent Sherman M. Fairchild at 31, Rosenfeld v. Fairchild Engine \& Airplane Corp., 309 N.Y. 168, 128 N.E. 2d 291 (1955). The Appellate Division opinion asserted that such representations did not "foreclose the possibility that the stockholders in their discretion would reimburse [the insurgents]." Rosenfeld v. Fairchild Engine \& Airplane Corp., 284 App. Div. 201, 210, 132 N.Y.S. 2d 273, 282 (3d Dep't, 1954).

To the extent that shareholder approval can be regarded as a "rubber stamp" the argument that insurgents have estopped themselves from obtaining reimbursement for at least some expenditures ought to receive greater consideration by the courts.

The latest proposed amendments to the Securities and Exchange Commission proxy rules would require detailed information concerning, inter alia, (1) the total present and estimated solicitation expenditures and the names of those who have paid, are committed to pay, or will pay them, and (2) "a specific statement of whether it is intended that (a) the issuer will be requested to pay the costs of the solicitation and (b) whether the payment of such cost will be submitted to a vote of security holders." 20 Fed. Reg. 6357, 6359, proposed Item 3(b) of Schedule 14A.

so Consult discussion of burden of proof at p. 694 infra. 
ment without prior shareholder approval upon provisions found in most state corporation statutes which place the power to run affairs of the corporation in the directors. ${ }^{31}$

\section{II}

With respect to insurgents who are ultimately unsuccessful in obtaining control, corporate reimbursement under proper safeguards might be justified on a concept of corporate benefit similar to that upon which the case for successful insurgents rests. ${ }^{32}$ Certainly, the determination of whether reimbursement is proper ought to depend mainly on the considerations involved in obtaining adequate shareholder information and participation and not entirely on the immediate outcome of that activity in any specific instance. The insurgents may in fact more accurately understand the corporate needs and yet fail for lack of personnel or financial resources. Successful incumbents may recognize the merit of and adopt some of the insurgent proposals, especially where the election vote was close. ${ }^{33}$

The need for encouraging insurgent proxy solicitation regardless of success is reflected in a recent study of Securities and Exchange Commission proxy registrations by non-management groups from 1951 through June 1954. It was concluded among other things that proxy contests are relatively rare, that they are not being used as a harassment device, and that they result primarily from poor or decadent management, mismanagement, and lack of dividend distributions. ${ }^{34}$ This study suggests that the advantages to be obtained from insurgencies would more than outweigh the dangers of increased "proxy-teering" which troubled the dissenting judges in the Rosenfeld case. ${ }^{35}$

${ }^{31}$ E.g., consult Cal. Codes Ann. (Deering, 1953) Corp. $\$ 800$; Ill. Rev. Stat. (1955) c. 32, $\S 157.33 ;$ N.Y. Gen. Corp. Law (McKinney, Supp., 1955) §27. There are, of course, specified exceptions such as the election of directors, merger or consolidation, charter amendments and similar fundamental changes in the character, organization, or existence of the corporation. Ballantine, Corporations $\$ 42$ (rev. ed., 1946).

${ }^{32}$ Many of the writers hold this view. Consult the articles cited supra note 1. Compare Corporations: Reimbursement for Corporate Campaign Expenses Incurred in Proxy Fights, 43 Calif. L. Rev. 893 (1955), in which the opposite conclusion regarding unsuccessful insurgents is reached.

${ }^{33}$ This appears, for example, to be the ultimate outcome of the recent Montgomery Ward Co.-Louis Wolfson proxy contest. Wall Street Journal, p. 22, col. 1 (Jan. 26, 1956).

${ }^{34}$ The study is found in two articles by Emerson and Latcham: Proxy Contests: Competition for Management Through Proxy Solicitation, supra note 1; Proxy Contests: A Study in Shareholder Sovereignty, 41 Calif. L. Rev. 393 (1953) (where it was concluded at p. 433 that "for the purpose of removing poor or decadent management, a proxy contest cannot but help to be beneficial. ...").

${ }^{35}$ In one article it was forcefully argued that, "[I] one is to be allowed the "indulgence' of suspicion of an insurgent non-management group, is there not then ground for at least an equal suspicion of an incumbent, decadent management? And is it not better, in any event, and indeed more democratic, to eliminate suspicion by hearing out all sides and by examining carefully their respective experience records and programs for company improvement and progress?" Emerson and Latcham, Proxy Contests: A Study in Sharehold Sovereignty, 41 Calif. I. Rev. 393, 433 (1953). 
In recognition of these considerations, a court might treat reimbursement upon majority shareholder approval as permissible-although in practice such approval appears extremely unlikely-provided the dispute concerned a bona fide policy matter and the expenditures were lawful in nature and reasonable in amount. ${ }^{36}$ Suppose, however, an action by unsuccessful insurgents to obtain corporate reimbursement. Due to the lack of precedent and the obvious danger of opening the corporate treasury to any disgruntled shareholder, the so-called "crack-pot," the court would probably refuse to force corporate expenditures without prior legislative action.

Formulation of the necessary deterring safeguard would seem best left to the legislature. The plan most frequently suggested is that the insurgent candidates be required to obtain a specified proportion of the shares voting in the election in order to be eligible for reimbursement of all proper expenditures. ${ }^{37}$ If such a scheme were adopted, no specific percentage less than fifty-one per cent would appear clearly more "reasonable" than any other. Thus the ten to fifteen per cent figure usually advocated seems as good as any, at least until further information is compiled. ${ }^{38}$

A more desirable alternative would be to allow reimbursement of a proportion of proper expenses, the amount to be governed by the percentage of voting shares obtained in the election. In computing the proportion of proper expendi-

${ }^{36}$ If prior to the election, the incumbent directors should allow reimbursement-as part of a compromise, for example-they might under some circumstances be vulnerable to derivative actions for negligence or breach of trust for misuse of corporate funds. Prudence may, therefore, prompt an attempt to gain shareholder approval of the settlement, even though it would not be a conclusive defense, where the derivative suit involves matters of "waste" of corporate funds or self-dealing. The possibility of collusion might lead one to prefer that such compromises be treated as settlements of derivative suits-the federal rules and some states requiring court approval and notice to the shareholders. Consult Ballantine, Corporations $\S 152$ (rev. ed., 1946).

${ }^{37}$ Consult, e.g., Latcham and Emerson, Proxy Contest Expenses and Shareholder Democracy, 4 West. Res. L. Rev. 5, 17 (1952); Friedman, Expenses of Corporate Proxy Contests, 51 Col. L. Rev. 951, 962 (1951). Mr. Friedman suggests reimbursement if, in the alternative, one insurgent director is elected under cumulative voting. No good reason appears for the discrimination between cumulative and ordinary voting procedure. In fact, this may be unfavorable where cumulative voting is combined with staggered elections or a small board of directors.

${ }^{38}$ The problem of arriving at a figure is exemplified by the process used to justify the percentage stated in the text. This was based upon a survey of shareholder responses to "shareholder proposals" submitted under SEC Proxy Rule X-14A-8, 17 Code Fed. Regs. \$ 240.14a8 (Cum. Supp., 1956). Latcham and Emerson, Proxy Contest Expenses and Shareholder Democracy, 4 West. Res. L. Rev. 5, 16-17 (1952). The resulting figure was an interpolation in recognition of the basic differences between Rule X-14A-8 proposals which relate primarily to cumulative voting, post-meeting reports, selection of auditors, etc., and the issues involved in a contested election such as ponr management and bad dividend policy. For a detailed analysis of these issues consult the following articles by Emerson and Latcham: Proxy Contests: Competition for Management Through Proxy Solicitation, 8 So. West. L.J. 403-17, (1954); Proxy Contests: A Study in Shareholder Sovereignty, 41 Calif. L. Rev. 393, 414, 416 (1953). 
tures for which reimbursement would be allowed, the percentage of votes obtained should be increased by a multiplier or series of multipliers. Under such a plan a capture of fifty per cent of the vote should result in reimbursement of virtually all proper expenses, while five per cent of the vote might be made to yield only three per cent or perhaps ten per cent of the proper expenses. This plan recognizes that unsuccessful insurgents ought not bear the entire cost of a legitimate campaign. On the other hand, the risk to the insurgents' own funds is likely to force a careful appraisal of the shareholders' reaction to the candidates and the proposals advocated, ${ }^{39}$ thereby providing the necessary safeguard against "crack-pot" activity.

\section{III}

Once the right of reimbursement is established, it becomes necessary to determine the nature and extent of the proxy solicitation expenditures for which corporate funds may ultimately be employed. The courts appear to regard successful insurgents as being entitled to reimbursement from corporate funds to the same extent as incumbent management. ${ }^{40}$ The rule as generally stated is that the incumbent management may

make such expenditures ... as are reasonably necessary to inform the stockholders of the considerations which the directors deem sufficient to support the wisdom of the policy advocated by them and under attack. ${ }^{41}$

This has provided very little assistance either to the courts or interested parties in determining which items are proper and how much may be expended for each. Apparently no reported case has disallowed incumbent expenditures as being

${ }^{39}$ This plan could be combined with still another scheme of "proportional reimbursement" suggested by Emerson and Latcham which is based on the rationale that the reimbursable amount of insurgents' expenses should vary also with the actual expenditures of incumbents who are able to draw on corporate funds as the costs are incurred. It is expressed by the formula:

Management expenses allowed $=$ Insurgent expenses allowed (X)

$\overline{\text { Votes secured by management }}=\overline{\text { Votes secured by insurgents }}$

Emerson and Latcham, Proxy Contests: A Study in Shareholder Sovereignty, 41 Calif. L. Rev. 393,436 (1953). Note that some adjustment in the formula would seem necessary to prevent the "outs," whose expenditures may be largely proper from suffering because of improperand perhaps more effective-expenditures by the "ins." For example, improper expenditures by incumbents for the entertainment of shareholders would probably be disallowed, thereby reducing the base for reimbursing the insurgents even though they may have refrained from any improper expenditures. To counter such a practice the insurgents may be forced to incur greater expense than otherwise necessary and yet be unable to obtain reimbursement for these "forced" expenditures.

${ }^{10}$ Cases cited note 2 supra.

41 Hall v. Trans-Lux Daylight Picture Screen Corp., 20 Del. Ch. 78, 81, 171 Atl. 226, 227 (1934). Consult the cases cited note 13 supra, and 5 Fletcher, Cyc. Corp. $\$ 2058.1$ (rev. ed., 1952). For an earlier view consult 3 Cook, Corporations $\S 610$ (8th ed., 1923) (allowing only expenditure for bare notice to shareholders). 
excessive, ${ }_{2}^{42}$ and although the above rule indicates that management may continue to answer the charges of the "outs," on the number of rounds which are "reasonable" when fought at the corporation's expense.

Insofar as the courts have considered the methods of solicitation used by incumbents, some inferences can be drawn concerning the type of expenditures for which the "outs" ought to be allowed reimbursement. The costs of printing and mailing proxy forms and interpretive supplements to the company's annual report would probably be allowed.44 While incumbents may properly use newspaper advertising to give widespread notice in some cases, the extent to which argumentative material may be included is not clear. ${ }^{45}$

The courts do not agree on the propriety of hiring professional proxy solicitors. ${ }^{46}$ While paid proxy solicitors may properly be employed on routine matters or even in contested elections where there may be difficulty in obtaining a quorum, ${ }^{47}$ their use does not seem "reasonably necessary to inform" the share-

2 But cf. Lawyers' Advertising Co. v. Consolidated Ry. Lighting \& Refrigerating Co., 187 N.Y. 395, 80 N.E. 199 (1907), disallowing certain expenditures as excessive. In addition, this case has been variously cited to indicate (1) that only the cost of proper notice is permissible, Rosenfeld v. Fairchild Engine \& Airplane Corp., 309 N.Y. 168, 176, 179, 128 N.E. 2d 291, 294, 296 (1955) (concurring and dissenting opinions); Steinberg v. Adams, 90 F. Supp. 604 (S.D. N.Y., 1950); Hall v. Trans-Iux Daylight Picture Screen Corp., 20 Del. Ch. 78, 171 Atl. 226 (1934); (2) that no expenditures for campaigns for control are proper, Rosenfeld v. Fairchild Engine \& Airplane Corp., supra, at p. 292 (Judge Froessel's opinion); (3) expenditures not approved by board of directors could not be authorized by the secretary, Rosenfeld v. Fairchild Engine \& Airplane Corp., 116 N.Y.S. 2d 840, 846 (S. Ct., 1952). Also consult note 5 supra.

43 This is also the view taken by the courts in the two insurgency cases apparently with respect to both incumbents and insurgents. See Rosenfeld v. Fairchild Engine \& Airplane Corp., 309 N.Y. 168, 172-73, 128 N.E. 2d 291, 292-93 (1955); Steinberg v. Adams, 90 F. Supp. 604 (S.D. N.Y., 1950).

"See Rascover v. American Linseed Co., 135 Fed. 341 (C.A. 2d, 1905) (report of company and industry condition); Hall v. Trans-Lux Daylight Picture Screen Corp., $30 \mathrm{Del}$. Ch. 78, 171 Atl. 226 (1934) following Peel v. London \& North Western Ry. Co. [1906], 1 Ch. Div. 5 (1907) (proxy forms); Bounds v. Stephenson, 187 S.W. 1031 (Tex. Civ. App., 1916) (notice and proxy forms).

${ }^{15}$ Compare Rascover v. American Linseed Co., 135 Fed. 341 (C.A. 2d, 1905), with Lawyers' Advertising Co. v. Consolidated Ry. Lighting \& Refrigerating Co., 187 N.Y. 395,80 N.E. 199 (1907). Consult Mich. L. Rev., op. cit. supra note 5.

16 Such expenditure has been held proper, In re Zickl, 73 N.Y.S. 2d 181 (S. Ct. 1947), and not subject to preliminary injunction, Hand v. Missouri-Kansas Pipe Line Co., 54 F. Supp. 649 (D. Del., 1944). See Lawyers' Advertising Co. v. Consolidated Ry. Lighting \& Refrigerating Co., 187 N.Y. 395, 80 N.E. 199 (1907) (where the court, at 399, 201, indicated that excess notices are improper by analogy to "dispatching special messengers for the purpose of procuring proxies in their [defendant's] behalf").

${ }^{47}$ This would probably be the view taken by the SEC. It has refused to allow the management of a public utility holding company to employ paid proxy solicitors with corporate funds in a contested election in the absence of a showing of "adequate cause." In the Matter of Standard Gas and Electric Co., 24 S.E.C. 337, 340-41 (1946). (It was specifically noted that there was no need in this case to assure a quorum.) Consult Loss, Securities Regulation 554 (1951); Loss, Securities Regulation 248 (Supp., 1955). 
holders in a contested election. Rather, as one writer has pointed out, the printed material generally distributed should adequately perform this function. The best policy, he concludes, is to deny both incumbents and insurgents the use of corporate funds for this purpose. ${ }^{48}$ This policy, however, would leave insurgents virtually unable to cope with incumbent use of the company's employees, especially salesmen, for personal solicitation. Paid proxy solicitors, therefore, might properly be used by insurgents under these circumstances.

The questions of which party must prove the nature and extent of actual reimbursements and establish their propriety deserve brief comment. The Rosenfeld decision places the burden of the first issue on the objecting shareholder, which, in view of the modern discovery procedures, ${ }^{49}$ seems a reasonable requirement.

The burden of establishing the propriety of reimbursement, on the other hand, should be upon the defendant directors, whose obvious financial interest in reimbursement requires application of the normal rule that a director must establish the fairness of a transaction between himself and his corporation. ${ }^{50}$ The extent to which a showing of shareholder approval discharges this burden is not clear. One writer has concluded from analogy to recent decisions concerning executive stock option plans (notably Gottlieb v. Heyden Chemical Corp.) ) $^{\text {t1 }}$ that upon approval the burden of proving the impropriety of reimbursement should be upon the plaintiff-shareholder. ${ }^{52}$ However, to the extent that such approval is virtually certain, this result becomes questionable, and one might prefer that approval be regarded as a "presumption of law" which is relegated to its probative value once the shareholder introduces contrary evidence. ${ }^{53}$

${ }^{48}$ Consult Friedman, Expenses of Corporate Proxy Contests, 51 Col. L. Rev. 951 (1951).

49 E.g., see Fed. Rules Civ. Proc. 26-37 and 53(c); Ill. Rev. Stat. (1955) c. 110, $\S 58$ and $101.17-101.20$; N.Y. Civil Practice Act Ann. (Gilbert-Bliss, 1942) $\$ \S 288-309$ and 322-26. The use of the Federal Rules is illustrated in Tobelman v. Missouri-Kansas Pipe Line Co., 130 F. 2d 1016 (C.A. 3d, 1942), and comprehensively discussed in 4 Moore, Fed. Practice (2d ed., 1950) $\$ \$ 26-37$.

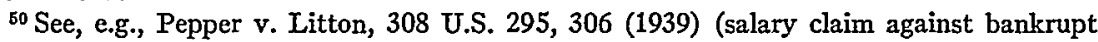
corporation); Geddes v. Anaconda Mining Co., 254 U.S. 590, 599 (1921) (common director of both corporations involved in transaction); and consult Ballantine, Corporations $\$ 70$ (rev. ed., 1946); 3 Fletcher, Cyc. Corp. $\$ 921$ (perm. rev. ed., 1947).

5133 Del. Ch. 177, 91 A. 2 d 57 (S. Ct., 1952).

52 Corporations: Reimbursement for Corporate Campaign Expenses Incurred in Proxy Fights, 43 Calif. L. Rev. 893, 900 (1955). The rule was strictly applied on remand by the Chancery court in the Gottlieb case, - Del. Ch. -, 99 A. 2d 507 (1953), which held against the plaintiff-shareholder for failure to introduce evidence that the shareholderapproved stock option was unreasonable when compared with compensation of executives similarly situated. A similar result has obtained in shareholder-approved profit sharing plans. See Rogers v. Hill, 289 U.S. 582 (1933); Heller v. Boylan, 29 N.Y.S. 2 d 653 (S. Ct., 1941). (The court remarked at p. 680 that it could not "by any reliable standard find [the payments] to be waste or spoliation.") But cf. Backus v. Finkelstein, 23 F. 2d 531 (D. Minn., 1924). (The court found executive salaries to be excessive, relying primarily on evidence of the company's weak financial condition.)

${ }^{53} \mathrm{~A}$ comprehensive explanation of the operation of presumptions of law may be found in 9 Wigmore, Evidence $\S \S 2487,2491$ (3d ed., 1940); McCormick, Evidence $\S \S 308,311$ (1954). 
Even accepting - as most courts probably would - the argument that the burden of establishing the impropriety of reimbursement is on the plaintiff-shareholder, the quantum of evidence required to satisfy the initial burden of producing evidence, i.e., the quantum necessary to make out a prima facie case, would be affected by: (1) the directors' superior access to pertinent information; and (2) the fact that it would be less difficult for the directors to establish that reasonable men could differ on the propriety of specific expenditures than for the plaintiff (as required by the Gottlieb case) ${ }^{54}$ to show that no reasonable man similarly situated would doubt the impropriety of the transaction.

The importance of the burden of persuasion in practice may be questioned. Once the facts are made known and evidence of propriety is introduced by both sides, the primary responsibility for determining the issue of "reasonableness" should rest with the court. ${ }^{55}$

\section{IV}

In short, the Steinberg-Rosenfeld position allowing corporate reimbursement of successful insurgents is sound and may be extended to allow-with appropriate limitations-the reimbursement of unsuccessful insurgents. The underlying policy considerations in favor of renewed use of proxy solicitations as a means of inducing increased shareholder participation and control of corporate affairs, however, would seem to justify greater development than is likely to be achieved within the confines of court decisions.

The development and enforcement of the basic policy modifications suggested could probably be accomplished best through a combination of legislation and administrative regulation. It could be provided by statute that insurgents are entitled to reimbursement regardless of ultimate success-provided some safeguard against "crack-pot" activities is adopted as suggested above-where the solicitation concerned a bona fide attempt to influence corporate policy.

As to the nature and content of reimbursable expenditures, it would seem desirable, although perhaps not essential, to establish a broad statutory standard which could be applied to specific cases by a designated agency such as the Securities and Exchange Commission ${ }^{56}$ or state agencies handling the present

54 This is the traditional effect of such conditions. McCormick, Evidence $\$ 318$, at p. 675 (1954); Chamberlayne, Trial Evidence $\$ 213$ (Tompkins ed., 1936).

${ }^{55}$ While the failure to satisfy the burden of producing evidence may well affect the outcome of a litigation, as in the Rosenfeld case, supra note 6, McCormick states that, "[t]his is much less true, it is believed, as to the burden of persuasion by itself. Occasionally a judge will rationalize his judgment as being based upon an equilibrium of mind, but he will do this infrequently and reluctantly, for it is a confession of defeat in the search for the truth and justice of the matter." McCormick, Evidence $\$ 322$, at 686 (1954).

so It is not clear whether the SEC would presently have authority to move this far into to regulation of the substantive relations between shareholders and management. The statutory authority seems primarily concerned with the method of soliciting proxies and insuring full disclosure, but a more liberal interpretation of congressional intent might be possible. 48 Stat. 895 (1934), 15 U.S.C.A. $\$ 78(\mathrm{n})$ (1951). On this question of legislative intent compare Friedman. Expenses of Corporate Proxy Contests, 51 Col. L. Rev. 951, 960-64 (1951), with 
"Blue Sky" laws. ${ }^{57}$ Thus, a standard of "expenses reasonably necessary to inform and advise the shareholders of the matters in question" could be given content through administrative regulation and application to specific situations. Such an approach would provide "continuous expert supervision, capable of ad hoc development to parallel the development of the subject matter involved. . . ."58 It would provide both uniformity and flexibility in dealing with the various complicating factors such as complexity of issues, size of corporation in terms of assets, earnings, current financial condition and character of stock distribution inherent in each case. ${ }^{59}$ Judicial review would be available to determine whether the agency has reasonably applied the statutory standard, ${ }^{60}$ but the volume of expensive, time-consuming litigation which might otherwise swamp the courts could be greatly reduced.

The effect of the Rosenfeld and Steinberg decisions is likely to be an increased use of the proxy solicitation machinery by shareholders. This comment has pointed to a few of the problems of law and policy which may be provided for through intelligent anticipation.

Caplin, Proxies, Annual Meetings and Corporate Democracy: The Lawyer's Role, 37 Va. L. Rev. 653, 682-85 (1951), and Friedman, SEC Regulation of Corporate Proxies, 63 Harv. L. Rev. 796, 819 (1950).

The present SEC rules are found in 17 Code Fed. Regs. $\$ 240.14 a-1$ to $240.14 a-10$ (Cum. Supp., 1956). The latest proposed amendments under consideration would require even more detailed information but do not attempt substantive regulation. 20 Fed. Regs. 6,357 (1955).

Greater control is exercised by the SEC over the solicitation of proxies by registered public utility holding companies, but under a broader statutory grant of authority. 49 Stat. 824 (1935), 15 U.S.C.A. $\$ 791$ (e) (1951). Rule U-65 prevents such a company from spending corporate funds in any calendar year in excess of $\$ 1,000$ plus the "[o]rdinary expenditures in connection with preparing, assembling, and mailing proxies, proxy statements, and accompanying data." 17 Code Fed. Regs. $\$ 250.65$ (1949). This rule was "intended to bring before this Commission all cases in which extraordinary expenditures are proposed by a company in connection with a proxy solicitation ... and for the specific purpose of preventing excesses and abuses in the expenditure of corporate funds in a proxy campaign." In re Standard Gas and Electric Co., 24 S.E.C. 337, 340-41 (1946). Apparently the rule was established in part to prevent large expenditures by a corporation for proxy solicitors in a contested election without prior Securities and Exchange Commission approval. SEC Holding Co. Act Release No. 2681 (April 9, 1941).

${ }^{57}$ Altbough there is great variation between the states, most such laws provide for some sort of administrative supervision. Consult Ballantine, Corporations $\$ \S 366,367$ (rev. ed., 1946); Loss, Securities Regulation 30-44 (1951).

${ }^{58}$ Gellhorn and Byse, Cases and Materials on Administrative Law 4 (1954).

${ }^{50}$ A similar formulation is to be found in Rosenfeld v. Fairchild Engine \& Airplane Corp., 116 N.Y.S. 2d 840,849 (S. Ct., 1952).

Variables such as these preclude the development of a fair and practicable legislative formula by which a limit on the amount of corporate funds to be used by both sides could be determined.

${ }^{80}$ See Gray v. Powell, 314 U.S. 402 (1941), establishing this test of the scope of judicial review of administrative agency action. 